0-077

原発性非小細胞肺癌に扔けるTS DNA polymorphismのTS発現調節と予後因子 としての役割

'大阪大学大学院 医学系研究科臟器制御外科, ${ }^{2}$ TSSG, 3獨協医科大学 胸部外科

\begin{abstract}
新谷 康 ${ }^{1}$, 太田 三徳', 平林 弘久', 田中 寿一'2, 井内 敬二 ${ }^{2}$, 中川 勝裕 ${ }^{2}$, 前田 元 $^{2}$, 城戸 哲夫 ${ }^{2}$, 三好 新一郎 ${ }^{3}$, 松田 暉 ${ }^{3}$
\end{abstract}

【背景】我々は thymidylate synthase（TS）mRNA 量が非 小細胞肺癌（NSCLC）の予後因子であると報告してきた。 一方, TS 遺伝子には28bpの repeat sequenceが存在しこ の polymorphismがTS発現に影響するとされる.【目的】 NSCLCに打りるDNA polymorphismとTS発現を比較し, 予後との関係を検討する。【対象】 NSCLC pStage I - II 70 例.【方法】mRNA 量; real time RT-PCR 法, 蛋白発現; 免疫染色, TS polymorphism; PCR 法.【結果】TS mRNA 量 $6.96 \pm 0.36$ (mean $\pm \mathrm{SD}:$ GAPDH r補正, Log). 免疫染色では 39 例が陽性. TS polymorphismは55例で triple-repeat (3R) とdouble-repeat $(2 \mathrm{R})$ を検出 L, 3R/ $3 \mathrm{R} ： 36$ 例， $3 \mathrm{R} / 2 \mathrm{R} ： 14$ 例， $2 \mathrm{R} / 2 \mathrm{R} ： 5$ 例であった. $3 \mathrm{R} / 3 \mathrm{R}$ では有意にTS mRNA 量が高く, 免疫染色陽性が多かった。 再発は 15 例に認め (平均観察期間； 3 年)，DFSに及ぼす 影響は, DNA polymorphism (3R/3R vs その他) ; p = 0.09 , TS mRNA level (高 vs 低) $; \mathrm{p}=0.008$, 免疫染色 (陽性 vs 陰性) ; $\mathrm{p}=0.34$ (Logrank test) で, 高mRNA が子後不良因子であった、【結語】DNA polymorphismは mRNA と相関し翻訳レベルでの調節機構が示唆され，TS mRNA 量とともに有意な予後因子となる可能性がある.

0-079 p-N2 非小細胞肺癌の発生肺葉別リンパ節 転移部位の検討

山形県立中央病院

正岡 俊明, 佐藤 徹, 金 哲樹

非小細胞肺癌に扔ける合理的なりンパ節郭清方法を探るこ とを目的とし, 非小細胞肺癌切除 704例中, 縦隔郭清を行 いpN2であった139例を対象に各肺葉別のリンパ節転移部 位を検討した。【結果】右上葉 $(\mathrm{n}=56)$ では上縦隔転移 53 例 $(95 \%)$ で分岐下転移も10例（18\%）に見られたが， 分岐下へのスキップ転移は2 例のみ（ともに進行例）であ った。右中葉 $(\mathrm{n}=13)$; 上縦隔転移 9 例 $(69 \%)$ ，分岐 下転移 8 例 $(62 \%)$ でスキップ転移も双方に見られた。右 下葉 $(\mathrm{n}=28)$; 分岐下転移 20 例 $(71 \%)$ で上縦隔転移 も 14 例 $(50 \%)$ に見られたが，上縦隔へのスキップ転移 は見られなかった. 左上葉 $(\mathrm{n}=26)$; 上縦隔・中縦隔 （\# 5，6）転移は 14 例 $(54 \%) \cdot 20$ 例 $(77 \%)$ で分岐下 も7例 $(27 \%)$ に見られたがスキップ転移は全て中縦隔で 分岐下には見られなかった。左下葉 $(\mathrm{n}=16)$ ；上縦隔・ 中縦隔·分岐下転移は7 例 $(44 \%) \cdot 10$ 例 $(63 \%) \cdot 8$ 例 (50\%) で，スキップ3例は全て中縦隔であった。スキッ プ転移は全体で 27 例 $(19 \%)$ で右下葉は1例 $(3.6 \%)$ の みであった、【まとめ】雨上葉では術中迅速診などで正確 に1群リンパ節転移なしと診断できれば分岐下の郭清は省 略できる可能性があると思われた，右下葉も同様に上縦隔 郭清を省略できる可能性があると思われた。
0-078 小細胞癌の集学的治療における外科療法の 意義

福井赤十字病院 呼吸器外科

平井 隆, 森川 洋匡, 山中 晃

【目的】LD小細胞肺癌に対する外科療法の意義を検討し た.【対象と方法】1989-2002年の小綀胞癌手術例 20 例 を対象とした. c-I 期は, 手術 +術後化療, c- II 期以上の 手術例は術前化療十手術の方針とした。化療は CDDP/CBDCA + VP-16を, 術前/術後で計 4 クール施行 した.【成績】男 17 例, 女 3 例で, 年齢は $45-75$ 歳（平均 61.4 歳)。非喫煙者 3 例，重喫煙者 17 例。臨床病期は I A 期 4 例, I B 期 3 例, II B 期 2 例, III A 期 9 例, III B 期 2 例であった。術前化療を 13 例に行いCR1, PR11, $\mathrm{NC} 1$ 例 であった，術式は葉切 15 例， 2 葉切 2 例, 全摘 1 例。術後 病期は 0 期 1 例, I A 期 7 例, I B 期 1 例, II A 期 1 例, II $\mathrm{B}$ 期 1 例 III A 期 5 例, III B 期 4 例であった. 4 例に組織学 的に heterogeneity 認めた。 c- I 期の 3 生率は $64.3 \%$, cII 期以上の 3 生率 $46.2 \%, 5$ 生率 $36.9 \%$ であった。再発を 7 例に認めたが，すべて 2 年以内であった。【結論】c- II 期 以上の小細胞癌でも 5 生率 $36.9 \%$ で, 外科療法により benefitを得られる groupが存在する。小細胞癌は最初の 2 年 間は特に厳重なfollowが必要である。

\section{O-080 染色体不安定性と肺癌の予後}

東京医科大学 第一外科

中村 治彦, 佐治 久, 緒方 昭彦, 萩原 優,

川崎 徳仁, 西條 天基, 加藤 治文

【目的】非小細胞肺癌の染色体不安定性（CIN）はよくわ かっていない，そこで，FISH法で検出した染色体不安定 性と㫗後との関係を検討した.【万法】非小細胞肺癌切除 例 50 例を対象とした。組織型は腺癌 34 例, 扁平上皮癌 15 例, 大細胞癌 1 例, 病理病期は I A 期 14 例, I B 期 17 例, II $\mathrm{B}$ 期 8 例, III A 期 9 例, III B期 2 例である. 切除腫場 の割面から作製した捺印標本を検体とし，FISH 法によっ て3番, 10 番, 11 番，17番の各染色体数を計数し CIN を 有する腫場を特定し, 生存率との関係を検討した。成績】 検討した各染色体において disomyが最も多かったが, trisomy, tetrasomy も高頻度に認められた。14例（28\%) がCINを有すると判定された。CINと組織型，病期には有 意な相関はなかった。生存率と各種予後因子を検討したと ころ，リンパ節転移の有無と, CINの有無が独立した予後 因子であり，CINを有する症例は有意に予後不良であった。 【結論】FISHで検出したCINは非小細胞肺癌の予後因子 として有用と考えられる。 